DOI: $10.22616 /$ j.balticsurveying.2018.020

\title{
RESEARCH OF COMPATIBILITY AND SYSTEMITY OF LAND MANAGEMENT TERMINOLOGY
}

\author{
Ihor Trevoho', Valery Riabchii ${ }^{2}$, Vladyslav Riabchii ${ }^{2}$ \\ ${ }^{1}$ Lviv Polytechnic National University, Ukraine \\ ${ }^{2}$ Dnipro Polytechnic National Technical University, Ukraine
}

\begin{abstract}
The analysis results of common terms in land management and their interpretations in normative-legal acts of Ukraine are presented. It have been established collisions and significant differences in the wording of even such common terms as a land parcel, a boundary of land parcel, a size of land parcel, etc. The purpose of the study is to identify collisions and contradictions of some key terms used in land surveying and geodetic works, as well as development of concrete proposals for improving and perfection the relevant terms. For this purpose, the following tasks were set and solved: analysis of regulatory legal acts of Ukraine concerning the conceptual apparatus of land management, systematization and generalization of substantiation results of the relevant terms correction need, development of proposals taking into account works content on land management and geodetic works for information provision of the State Land Cadastre. In the course of the study, the comparative method of analysis and the systematization of inconsistencies in the current normative legal acts of Ukraine regarding the terms and their interpretation are used. During the proposals development, known approaches "from general to partial" and vice versa were used. The established disadvantages do not allow unambiguously interpreting and performing such important work as geodetic setting or restoration of the land parcels boundaries, resolution of land disputes between adjacent users of land parcels. Completed summaries of content and wording of the relevant terms justify a need for correction of the terms and additions to their definitions. It was set the features of each term. As a result of integrated approach to solution of the existing problem and systematization of established differences, the general wording and detailed specification of the analyzed terms interpretations are proposed. Knowledge of technological stages for geodetic and land management works provided an opportunity to improve the geodetic information support of the State Land Cadastre. The proposals for correction of the studied terms eliminate existing contradictions, provide an unambiguous interpretation of land management terminology, which leads to the exact execution of geodetic and land management works, and, accordingly, obtaining reliable information for the State Land Cadastre.
\end{abstract}

Key words: land management, land parcel, boundary of land parcel, size of land parcel.

\section{Introduction}

In the society, development of land resources always plays a leading role. Therefore, one of the decisive factors that determines the paces and efficiency of land management and cadastre developments in Ukraine is the specification and improvement of the land legislation terminology of Ukraine and methodological and technological procedures. It's specification and improvement remains important and relevant.

The basis for correct and unambiguous understanding in science, technology and production are terms. Each science and specialty has their own peculiarities in the terminology that characterizes the professionalism and qualification of its specialists. One of high level indicators of professionalism in any industry is unambiguous interpretation of terms and concepts.

Since various definitions of the same term, ambiguous interpretation or no explanation exists in the normative legal acts of Ukraine, this leads to an unsatisfactory state of land management terminology. Some existing contradictions in terms of land management are found even by curious students. Therefore, solving the problem of correction and specification terminology in the normative legal acts of Ukraine is relevant and important for land management and improvement of the educational process.

The purpose of the study is to identify collisions and contradictions of some key terms used in land surveying and geodetic works, as well as development of concrete proposals for improving and perfection the relevant terms. 


\section{Methodology of research and materials}

Below an analysis of some the most common terms that are used not only in land law, but also in everyday life of almost every citizen of Ukraine is given.

Determination of such a widespread term as a land parcel, even in the Land Code of Ukraine dated 25.10.2001 No. 2768-III with changes introduced by the law of Ukraine from 05.09.2017 No. 2145VIII and the Tax Code of Ukraine dated 02.12.2010 No. 2755-VI with changes introduced by the law of Ukraine from 07.09.2017 № 2146-VIII are different. Thus, in accordance with Article 79 of the Land Code of Ukraine, a land parcel is a part of the earth's surface with established boundaries, a specific location, with the rights assigned to it. Ownership of the land parcel extends within its boundaries to the surface (ground) layer, as well as water objects, forests and perennial plantations, that are located on it, unless otherwise provided by law and do not violate the rights of other persons. Ownership of the land parcel extends over the space above and below the surface of the land parcel to the height and depth necessary for the construction of residential, industrial and other buildings and structures.

In subparagraph 14.1.74 of the Tax Code of Ukraine, "the land parcel is a part of the earth's surface with established boundaries, a specific location, intended (economic) purpose and the rights determined in relation to it".

The definition of the term land parcel provided in the Land Code of Ukraine is duplicated: Article 1 of the Law of Ukraine "On Land Valuation" dated 11.12.2003 No. 1378-IV with changes introduced by the law of Ukraine from 02.03.2015 No. 222-VIII, paragraph 2 of the National Standard No. 2 "Real estate valuation" dated 28.10.2004 No. 1442 with changes introduced by the decision of the Cabinet of Ministers of Ukraine from 31.03.2015 No. 168, paragraph 1.2 of the Regulation on the organization of apartment maintenance of the Armed Forces of Ukraine, approved by the order of the Ministry of Defence of Ukraine dated 03.07.2013 No. 448 with changes introduced by the order of the Ministry of Defence of Ukraine from 04.08.2015 No. 383, and paragraph 3 of the Classifier of State property dated 15.03.2006 No. 461448 with changes introduced by the order of the State Property Fund of Ukraine from 14.07.2013 No. 840.

There are other options for defining this term different from the previous ones. In paragraph 1.5 of the Technical instructions on determination of boundaries of land parcels of joint and common partial ownership of individuals and legal persons in the built-up territory in settlements approved by the order of the State Committee of Ukraine for Land Resources dated 18.05.1998, it is stated that "The land parcel is a plot of land, that is subject to homogeneous property rights and that is a single property, has fixed boundaries and is characterized by a certain location, natural properties, physical parameters, legal and economic status and other characteristics that are its essential components".

In accordance with paragraph 1 of the Provisional methodical instructions on the assignment of cadastral numbers to land plots for the maintenance of the state land cadastre (with amendments) dated 26.01.1998 No. 1 "The land parcel - part of the earth's surface, that has fixed geometric and legal boundaries and is the base unit of the land registry cadastre".

In accordance with paragraph 1.3 of the Order on the organization of the objects protection and premises in which drug-containing plants are cultivated, used, stored and destroyed, as well as final products received from them or waste from such plants are used, stored and destroyed, approved by the order of the Ministry of Internal Affairs of Ukraine dated 27.10.2010 No. 507, "The land parcel is a field where drug-containing plants are cultivated, used, stored and destroyed, as well as final products obtained from them or waste of such plants are used, stored and destroyed".

According to the Geodesic encyclopedic dictionary (Geodetic encyclopedic dictionary, 2001), "Land parcel - a part of the earth's surface that is spatially limited by a closed external boundary and is the object of possession or use and is registered as a unit of account in a land registry system".

In the Glossary of Terms in the Field of Land Relations and Land Use (Glossary of Terms in Land Relations and Land Use, 2008), in general, seven definitions of the term land parcel are given.

According to Article 1 of the Forest Code of Ukraine dated 21.01.1994 No. 3852-XII with changes introduced by the law of Ukraine from 23.05.2017 No. 2063-VIII, "The forest land parcel is a land plot of a forest fund of Ukraine with specified boundaries, that is provided or withdrawn from the land user or the owner of a land plot for forest management or other public needs in accordance with the land legislation". 
According to paragraph 3 of general part of the Collection of aggregate indicators of the cost of reproduction of functional analogues for the evaluation of low-rise buildings, buildings and structures dated 23.12.2004 No. 2929," smallholding land parcel - a land plot (boundaried, provided with exit to the street, lane, etc.), on that are located a residential building, household buildings, a garden, a croft, etc."

In accordance with Article 1 of the Law of Ukraine "About sea ports" dated 17.05.2012 No. 4709-VI with changes introduced by the law of Ukraine from 04.07.2013 No. 406-VII, "artificially created land parcel is a land plot established (washed out, poured, created with the use of other technologies) within the water area of the seaport".

\section{Discussion and results}

\section{Polysemy of term land parcel}

Interpretations of the land parcel term are summarized in the table 1 (Riabchii V.A., Riabchii V.V., Khomiak Yu.Ye., 2012, Riabchii V.A., Riabchii V.V., Khomiak Yu.Ye., 2013, Riabchii V.V., Khomiak Yu.Ye., 2013).

Table 1

The generalization of comparing results of land parcel term definition in the normative legal acts of Ukraine

\begin{tabular}{|c|c|}
\hline Definition of land parcel term & References to normative legal acts of Ukraine \\
\hline $\begin{array}{l}\text { It is a part of the earth's surface with established } \\
\text { boundaries, a specific location, with defined rights to it }\end{array}$ & $\begin{array}{l}\text { - Article } 79 \text { of the Land Code of Ukraine; } \\
\text { - Article } 1 \text { of the Law of Ukraine "On Land Valuation"; } \\
\text { - paragraph } 2 \text { of the National Standard No. } 2 \\
\text { "Estimation of Real Estate" } \\
\text { - paragraph } 1.2 \text { of the Regulation on the organization of } \\
\text { apartment maintenance of the Armed Forces of Ukraine; } \\
\text { - paragraph } 3 \text { of the Classifier of State Property"; }\end{array}$ \\
\hline $\begin{array}{l}\text { It is a part of the earth's surface with established } \\
\text { boundaries, a specific location, intended (economic) } \\
\text { purpose and determined in relation to it }\end{array}$ & sub-paragraph 14.1.74 of the Tax Code of Ukraine \\
\hline $\begin{array}{l}\text { It is a plot of land, that is subject to homogeneous } \\
\text { property rights and that is a single property, has fixed } \\
\text { boundaries and is characterized by a certain location, } \\
\text { natural properties, physical parameters, legal and } \\
\text { economic status and other characteristics that are its } \\
\text { essential components }\end{array}$ & $\begin{array}{l}\text { paragraph } 1.5 \text { of the Technical instructions on } \\
\text { determination of boundaries of land parcels of joint and } \\
\text { common partial ownership of individuals and legal } \\
\text { persons in the built-up territory in settlements }\end{array}$ \\
\hline $\begin{array}{l}\text { It is part of the earth's surface, that has fixed geometric } \\
\text { and legal boundaries and is the base unit of the land } \\
\text { registry cadastre }\end{array}$ & $\begin{array}{l}\text { paragraph } 1 \text { of the Provisional methodical instructions } \\
\text { on the assignment of cadastral numbers to land plots for } \\
\text { the maintenance of the state land cadastre }\end{array}$ \\
\hline $\begin{array}{l}\text { It is a part of the earth's surface that is spatially limited } \\
\text { by a closed external boundary and is the object of } \\
\text { possession or use and is registered as a unit of account } \\
\text { in a land registry system }\end{array}$ & Geodetic encyclopedic dictionary \\
\hline
\end{tabular}

In addition to the interpretations in the normative legal acts of Ukraine, the term "land parcel" are cases where the authors of some publications (Andreitsev V.I., 2007, Kalynichenko Yu., Sai V., 2014, Miroshnychenko A.M., 2011, Nosik V.V., 2006, Trehub M., 2012, Shulha M.V., 1998) give their interpretation and explanation of this term. Each of these formulations has its own content, and each of them has its own specific features, but there is no unambiguousness, and all these definitions reflect the more legal side of this term. For example, the spatial, individually determined and legally separate surface part of the corresponding category of land, the boundaries of which are established on the ground and fixed in the land legal documents that certify its belonging to the corresponding legal title to owners or users for the purposeful use as a means, conditions and sources of life and satisfaction of material, social, ecological, spiritual, other needs and interests of the person (Andreitsev V.I., 2007) or located above the subsoil of the earth's surface, that is the basis of the 
landscape, immovable in the location, individually determined in a particular area by size, boundary, function purpose, as well as by the law, administrative act or contract, the rights and obligations of citizens and legal entities and other subjects of the land rights (Nosik V.V., 2006), or part of the earth's surface, that is the basis of the landscape, has a fixed area, boundary and location, and is characterized by a certain qualitative state and its legal status (Shulha M.V., 1998), etc.

In the practice of land management, in accordance with the Land Code of Ukraine, there are also terms with the following phrases: land for farming, for the maintenance of a private peasant farm, for gardening, for the construction and maintenance of a dwelling house, household buildings and structures (private parcel), for an individual cottage construction or for the construction of individual garages, etc., but this is more than the intended purpose of the land parcel.

Based on logical and hierarchical considerations, it is necessary to choose the standard term given in the Land Code of Ukraine, but it is also not perfect, since it does not reflect all the features of existing land parcels. So in the Land Code of Ukraine there are four main features of the land parcel:

- part of the earth's surface;

- has set boundaries;

- there is a specific location;

- rights determined in relation to it.

However, two last signs are contradictory, since a land parcel cannot be without a specific location and not always in the course of the existence of the land parcel there are certain rights. For example, it is obvious that a land parcel exists until the registration of rights to it.

In wording this term, the Land Code of Ukraine and other normative legal acts of Ukraine do not take into account those facts that the land may be subject to restrictions and encumbrances, land improvements (real estate, perennial plantings, natural vegetation, etc.) may be included there in. There is no interpretation of the right of lease of the land parcel, its prevalence in vast that located on and below the surface of the land parcel, etc.

\section{Polysemy of term boundary of the land parcel}

In the normative legal acts of Ukraine there are such formulations of the term "boundary of the land parcel".

In Article 1 of the Law of Ukraine "On state control over the use and protection of land" dated 19.06.2003 No. 963-IV with changes introduced by the law of Ukraine from 23.12.2015 No. 901-VIII, is the definition that "the boundary of the land parcel is a conditional closed polygon that separates land parcels".

According to paragraph 1.3 of the Instruction on the establishment (restoration) of the boundaries of land parcel in nature (on the ground) and their affixing by boundary marks, approved by the order of the State Committee of Ukraine for Land Resources dated 18.05.2010 No. 376 with changes introduced by the order of the Ministry of Agrarian Policy and Food of Ukraine from 03.07.2013 No. 405, "the boundary of the land parcel - a set of lines forming a closed loop and separating land parcels ".

According to the Technical instructions on determination of boundaries of land parcels of joint and common partial ownership of individuals and legal persons in the built-up territory in settlements, given the following wording: "the boundary of land parcel - ground material turning point, indicating the boundaries of the land parcel, or the conditional line on the surface, that divides two invented parcels".

According to paragraph 3 of general part of the Collection of aggregate indicators of the cost of reproduction of functional analogues for the evaluation of low-rise buildings, buildings and structures, "the boundary is the minimum width of the land strip that separates one land parcel from another (from the street, the passage, etc.)".

In the Geodetic encyclopedic dictionary (2001), this notion is interpreted as "the legally defined line, depicted on maps or set in a digital model of terrain and fixed on the ground by natural or physical contours or corresponding turning point."

In addition, normative legal acts of Ukraine have such notions as: 
- the boundary of a district, village, town, city, city district- is a conditional closed line on the surface of the land, which separates the territory of the district, village, town, city, city district from other territories (in accordance with Article 173 of the Land Code of Ukraine);

- the boundary of the city - the outer boundary of the city lands, which separates them from land of other purpose and determined by the city planning and development project or the feasibility study of the city development (in accordance with the Land Code of the Ukrainian Soviet Socialist Republic);

- the common boundary of the land parcels - the boundary at which the exact line separating the land parcels is not established (according to paragraph 1.5 of the Technical instructions on determination of boundaries of land parcels of joint and common partial ownership of individuals and legal persons in the built-up territory in settlements);

- legal boundary - an airspace that determines where the ownership of one land parcel is conditionally terminated and the property of another begins. It is not locally established (in accordance with clause 5.6 of the Technical instructions on determination of boundaries of land parcels of joint and common partial ownership of individuals and legal persons in the built-up territory in settlements).

Analysing the above concepts of boundaries of the land parcel, one can see that there are differences between them and not all the peculiarities of using the notion of boundary are taken into account. Any of these concepts of the land parcel boundaries do not fully disclose its contents.

\section{Uncertainty of concepts metric data and size of the land parcel}

The term metric data (information, low-down) of the land parcel is used in some normative legal acts of Ukraine (paragraphs 21, 27, 28, 37, 44, 45 and 67 of Annex 1 to the Procedure for the State Land Cadastre dated 17.10.2012 No. 1051, paragraph 1.2 of the Instruction on the establishment (restoration) of the boundaries of land parcel in nature (on the ground) and their affixing by boundary marks, etc.) These three concepts (data, information and low-down) are similar in content, but are different things. In land management and cadastre, the use of term "metric data of the land parcel" is more correct.

Let's analyze the concept of "size of the land parcel". In the Land Code of Ukraine, this term is set out in many articles, in particular 25, 31, 32, 41, 42, 63, 64, 66, 88, 89, 118-121, 123, 137, 139, 151 and 211. In the Civil Code Ukraine dated 16.01.2003 No. 435-IV with changes introduced by the law of Ukraine from 03.10.2017 No. 2147-VIII, it was fixed in Articles 325, 377 and 796. In Articles 35 and 47 of the Law of Ukraine "On Land Management" dated 22.05.2003 No. 858-IV with changes introduced by the law of Ukraine from 17.01.2017 No. 1817-VIII, and Article 15 of the Law of Ukraine "On Land Leasing" dated 06.10.1998 No. 161-XIV with changes introduced by the law of Ukraine from 23.03.2017 No. 1983-VIII, also term "the size of the land parcel" is given. That is, this term is actually approved, but its specific wording or interpretation in these normative legal acts of Ukraine is not given.

According to paragraph 2.3 of the Technical instructions on determination of boundaries of land parcels of joint and common partial ownership of individuals and legal persons in the built-up territory in settlements, "the size of the land parcel is characterized by physical and analytical areas". But, what is the size of the land parcel, there is no specific wording or interpretation in this normative legal act of Ukraine. If under the size of the land parcel to understand only its area, it is also not quite correct, because there are other indicators without which the characteristics of the land will be incomplete.

In addition, according to part 2 of Article 128 of the Land Code of Ukraine "... the application indicates the location of the land parcel, its intended purpose, size and area, as well as agreement to conclude a contract about advance payment for the land parcel price". From this it turns out that the size of the land parcel is not its area.

\section{Conclusions and recommendations}

As a result of analysis and comparison of land management terms in the normative legal acts of Ukraine, significant differences are found in their wording and interpretations. Some commonly used 
terms, such as the land parcel, the boundary of land parcel, metric data of land parcel, etc., are not commonly formulated and detailed.

\section{References}

1. Andreitsev V.I. (2007) Zemelne pravo i zakonodavstvo suverennoi Ukrainy (Land law and legislation of sovereign Ukraine). Kyiv, Znannia. 445 p. (in Ukrainian).

2. Heodezychnyi entsyklopedychnyi slovnyk (Geodetic encyclopedic dictionary) (2001). Lviv, Yevro svit. 668 p. (in Ukrainian)

3. Kalynichenko Yu., Sai V. (2014) Kontseptualni zasady pravovoho rehuliuvannia zemelnykh vidnosyn (Conceptual principles of legal regulation of land relations) Suchasni dosiahnennia heodezychnoi nauky ta vyrobnytstva (Modern achievements in geodetic science and production). Vyp. 1 (27), p. 62-66 (in Ukrainian).

4. Miroshnychenko A.M. (2011) Zemelne pravo Ukrainy (Land law of Ukraine). Kyiv, Alerta: Tsentr uchbovoi lit. 680 p. (in Ukrainian).

5. Nosik V.V. (2006) Pravo vlasnosti na zemliu Ukrainskoho narodu (Ownership of the land for the Ukrainian people). Kyiv, Khrinkom Inter. 544 p. (in Ukrainian).

6. Riabchii V.A., Riabchii V.V., Khomiak Yu.Ye. (2012) Analiz zmistu ta tlumachennia deiakykh terminiv u zemelnomu zakonodavstvi (Analysis of the content and interpretation of some terms in land legislation). Zbirnyk prats III Vseukrainskoi naukovo-tekhnichnoi konferentsii studentiv, aspirantiv i molodykh vchenykh «Naukova vesna 2012» (Collected Works of the 3rd All-Ukrainian Scientific and Technical Conference of Students, Postgraduates and Young Scientists «Scientific Spring 2012»), Dnipropetrovsk, 29 bereznia 2012 r. Dnipropetrovsk, p. 143-144 (in Ukrainian).

7. Riabchii V.A., Riabchii V.V., Khomiak Yu.Ye. (2013) Tlumachennia terminiv zemelnoho zakonodavstva u normatyvno-pravovykh aktakh Ukrainy (Interpretation of the terms of the land legislation in the normative legal acts of Ukraine). Naukovyi visnyk Uzhhorodskoho universytetu. Seriia Heohrafiia. Zemleustrii. Pryrodokorystuvannia (Scientific herald of Uzhgorod University. Series Geography. Land management. Nature use), Vyp. 1, p. 93-97 (in Ukrainian).

8. Riabchii V.V., Khomiak Yu.Ye. (2013) Analiz zmistu normatyvno-pravovykh aktiv Ukrainy stosovno deiakykh terminiv ta yikh tlumachennia (Analysis of the content of Ukrainian legal acts on certain terms and their interpretation). Inzhenerna heodeziia (Engineering geodesy), Vyp. 59, p. 61-70 (in Ukrainian).

9. Slovnyk terminiv u sferi zemelnykh vidnosyn ta zemlekorystuvannia (Glossary of Terms in Land Relations and Land Use) (2008). Derzh. kom. Ukrainy iz zemelnykh resursiv. Kyiv, Avhust Treid. 240 p. (in Ukrainian).

10. Trehub M. (2012) Propozytsii shchodo udoskonalennia terminiv u derzhavnomu zemelnomu kadastri Ukrainy (Proposals for improving the terms in the state land cadastre of Ukraine). Inzhenerna heodeziia (Engineering geodesy), Vyp. 58, p. 78-87 (in Ukrainian).

11. Shulha M.V. (1998) Aktualnye pravovye problemy zemelnykh otnoshenyi v sovremennykh uslovyiakh (Actual legal problems of land relations in modern conditions). Kharkov, Konsum. 224 p. (in Ukrainian).

\section{Information about authors}

Ihor Trevoho, Doctor of Technical Sciences, Professor, President of Public Union "Ukrainian Society of Geodesy and Cartography", Dean of Institute of Geodesy, Professor of Department of Geodesy of Lviv Polytechnic National University, 12 Bandery St., Lviv, Ukraine, 79013, e-mail: itrevoho@gmail.com

Valeri Riabchii, Associated Professor of Department of Geodesy of Dnipro Polytechnic National Technical University, 19 Dmytra Yavornitskogo Av., Dnipro, Ukraine, 49005, e-mail: ryabchyv@nmu.org.ua

Vladislav Riabchii, Associated Professor, Head of Department of Geodesy of Dnipro Polytechnic National Technical University, 19 Dmytra Yavornitskogo Av., Dnipro, Ukraine, 49005, e-mail: ryabchyv@nmu.org.ua 